\title{
VULNERABILIDADE AMBIENTAL À EROSÃO HÍDRICA NA SUB-BACIA DO CÓRREGO DO GUANABARA/ RESERVA DO CABAÇAL-MT BRASIL
}

\author{
Marcel do Nascimento CUIABANO ${ }^{1}$, Sandra Mara Alves da Silva NEVES ${ }^{2}$, Maria Cândida \\ Moitinho NUNES ${ }^{3}$, Milson Evaldo SERAFIM ${ }^{4}$, Ronaldo José NEVES ${ }^{5}$
}

(1) Graduado em Engenharia Agronômica da Universidade do Estado de Mato Grosso-Campus Cáceres. Endereço eletrônico: marcel_nasc@hotmail.com

(2) Doutora em Geografia, Docente do curso de Geografia da Universidade do Estado de Mato Grosso-Campus Cáceres. Endereço eletrônico: ssneves@unemat.br

(3) Doutora em Ciência do Solo, Docente do Departamento de Solos da Faculdade de Agronomia Eliseu Maciel. Universidade

Federal de Pelotas. Endereço eletrônico: nunes.candida@gmail.com

(4) Doutor em Ciência do Solo, Docente e Diretor do Dep. de Desenvolvimento Educacional - IFMT Cáceres. Endereço eletrônico: milsonserafim@gmail.com

(5) Doutor em Geografia, Docente do curso de Geografia da Universidade do Estado de Mato Grosso-Campus Cáceres. Endereço eletrônico: rjneves@terra.com.br

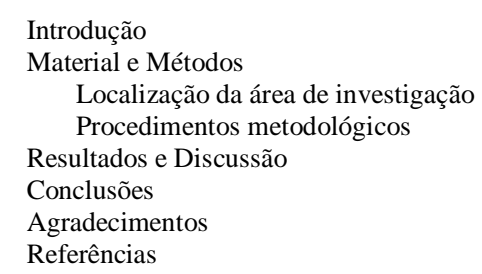

RESUMO - Este estudo objetivou avaliar a suscetibilidade à erosão hídrica como indicador de vulnerabilidade ambiental da subbacia do Córrego do Guanabara no município de Reserva do Cabaçal-MT. O mapa de erodibilidade foi elaborado através da associação dos tipos de solos com classes de erodibilidade. A combinação do mapa de erodibilidade com o do fator topográfico originou o mapa de susceptibilidade à erosão. O mapa do potencial à erosão foi obtido pela combinação do mapa de susceptibilidade à erosão com o de uso atual da terra. Foram coletadas amostras, deformadas e indeformadas, na camada de 0,0-0,1m e 0,1-0,2m, em ambientes considerados como degradado, moderadamente degradado e natural. A sub-bacia apresenta predominância de Neossolos Quartzarênicos (62,06\%), sendo que $91,90 \%$ de sua área se apresentam extremamente susceptíveis à erosão hídrica e 8,10\% muito susceptível à erosão hídrica. A textura do solo não se diferiu nos ambientes estudados, porém demonstrou a predominância da fração areia, o que é característico desse tipo de solo. $\mathrm{O}$ ambiente natural apresentou maior quantidade de macroagregados estáveis em água. A análise de vulnerabilidade se torna importante, pois fornece informações sobre a maior ou menor susceptibilidade de um ambiente ao processo de erosão, fornecendo ferramentas para o adequado planejamento, uso e ocupação do solo.

Palavras-chave: geotecnologia, degradação do solo, uso da terra, atributos físicos.

\begin{abstract}
This study aimed to evaluate the susceptibility to erosion as an indicator of environmental vulnerability of the Subbasin of Guanabara stream in the municipality of Reserva do Cabaçal-MT. The erodibilidade map was prepared by the association of soil types with erodibilidade classes. The combination of the erodibilidade map with the topographic factor originated the map of susceptibility to erosion. The map of potential erosion was obtained by combining the map of susceptibility to erosion with the current use of the land. Samples were collected, deformed and undeformed, 0.0-layer $0.1 \mathrm{~m}$ and 0.1-0.2m, in environments considered as degraded, moderately degraded and natural. The sub features a predominance of Neossolos Quartzarênicos $(62.06 \%)$, with $91.90 \%$ of its area are extremely susceptible to erosion and $8.10 \%$ very susceptible to water erosion. The soil texture not differed in studied, but demonstrated the predominance of the sand fraction, which is characteristic of this type of soil. The natural environment was more stable in amount of macroagregados water. The vulnerability analysis becomes important, as it provides information about the greater or lesser susceptibility to an environment the process of erosion, providing tools for appropriate planning, use and occupation of the soil.
\end{abstract}

Keywords: geotechnology, soil degradation, land use, soil physics.

\section{INTRODUÇÃO}

As diversas formas de ocupação do meio ambiente acarretam em desequilíbrios, pois os ambientes naturais mostram-se ou mostravamse em estado de equilíbrio dinâmico até o momento em que as sociedades humanas passaram progressivamente a intervir intensamente na exploração dos recursos naturais (Ross, 1993). Messias et al. (2012) relatam que a ação antrópica tem transformado o meio natural devido aos modelos de consumo atuais, não o utilizando como um sistema que garante a sua sobrevivência, mas como recurso financeiro. Assim, a ação antrópica na natureza afeta a funcionalidade do sistema e induz aos processos degenerativos (Amaral \& Ross, 2009).

A vulnerabilidade ambiental, de acordo com o Ministério do Meio Ambiente (2007), pode 
ser definida como grau de susceptibilidade em que um componente do meio, de um conjunto de componentes ou de uma paisagem apresentam em resposta a uma ação, atividade ou fenômeno. Nesse sentido, Tagliani (2003) indica que a vulnerabilidade ambiental significa a maior ou menor susceptibilidade de um ambiente a um impacto potencial provocado por um uso antrópico qualquer.

O potencial de um solo à erosão hídrica pode ser um indicador adequado da vulnerabilidade ambiental em um dado local. A erosão do solo é um processo que consiste na separação das partículas individuais a partir da massa do solo e seu transporte por agentes erosivos, como escoamento superficial e vento. Quando a energia disponível não é mais suficiente para transportar as partículas, ocorre a deposição (Morgan, 2005). Atributos físicos, principalmente estrutura, textura, permeabilidade e densidade, assim como químicos e biológicos variam de acordo com tipo de solo e exercem diferentes influências sobre a erosão (Bertoni \& Lombardi Neto, 2014).

A erodibilidade é definida como a resistência do solo à desagregação e transporte e varia com a textura do solo, a estabilidade de agregados, a força de cisalhamento, a capacidade de infiltração e com o conteúdo químico e orgânico (Morgan, 2005).

A descrição detalhada de atributos do solo e de variáveis do espaço físico é indispensável para o planejamento adequado do uso da terra, levando-se em conta, ainda, que as relações entre esses atributos são extremamente complexas (Alvarenga \& Paula, 2000). As diferenças nos atributos físicos e químicos explicam em muitos casos o fato de alguns solos erodirem mais que outros, mesmo estando expostos a mesma condição e ambiente. Outro elemento que interfere no processo erosivo é o tipo de uso da terra e a cobertura vegetal. Além de proteger o solo contra a perda de material, o uso adequado e a cobertura vegetal o protege direta e indiretamente contra os efeitos modificadores das formas do relevo (Kawakubo et al., 2005). A vegetação natural é um importante indicador das condições ambientais, uma vez que propicia proteção ao solo, reduzindo o transporte de sedimentos e o assoreamento dos corpos d'água, além de servir de habitat para animais silvestres, contribuindo, desta forma, para manutenção da biodiversidade (Campos \& Neves, 2009). A vegetação existente em determinada área pode influenciar de forma significativa a agregação do solo e a resistência à desagregação (Costa Júnior et al., 2011).

A estabilidade de agregados avalia a capacidade das estruturas secundárias do solo em resistir à erosão (D’Andréa et al., 2002) e relaciona-se diretamente com a densidade, porosidade, aeração, capacidade de retenção e infiltração de água no solo e disponibilidade de nutrientes (Campos, 2012). Dessa forma, solos com melhor agregação têm menor erodibilidade.

Áreas classificadas como ambientalmente vulneráveis são aquelas que mesmo em condições de paisagem natural apresentam solos jovens e pouco desenvolvidos, com pequena evolução dos perfis de solo, a exemplo, dos Neossolos e Organossolos (Crepani et al., 2001). Os Neossolos são constituídos por material mineral, ou por material orgânico pouco espesso, que não apresentam alterações expressivas em relação ao material originário em razão da sua maior resistência ao intemperismo ou por influência dos demais fatores de formação (clima, relevo ou tempo), que podem impedir ou limitar a evolução desses solos (Embrapa, 2006). Em geral, os Neossolos apresentam grau de erodibilidade moderada a alta e pequena profundidade efetiva, havendo assim a necessidade de um manejo conservacionista em áreas em que este solo seja predominante (Margolis et al., 1985).

A utilização agrícola dos Neossolos Quartzarênicos pode causar prejuízos ambientais. Souza et al. (2005) indicam que o uso e o manejo do solo promovem alterações na densidade do solo, porosidade total e macroporosidade, em maior intensidade no Neossolo Quartzarênico do que no Latossolo Vermelho. Assim, sistemas intensivos e inadequados de uso e manejo do solo pode influenciar em seus atributos físicos, predispondo-os a degradação e causando prejuízos à sustentabilidade dos mesmos. Neste sentido, torna-se indispensável o uso da terra de acordo com a sua capacidade de uso. A capacidade de uso da terra (CAUT) pode ser 
conceituada como a adaptabilidade da terra às diversas formas de utilização agrícola, sem que ocorra o depauperamento do solo pelos fatores de desgaste e empobrecimento, através do seu uso (Lepsch et al., 1991). As classes de capacidade de uso representam um grupamento de terras com o mesmo grau de limitação, considerando a possibilidade de serem utilizadas para culturas anuais, culturas perenes, pastagens, reflorestamento ou vida silvestre, sem sofrerem danos consideráveis.

O uso e ocupação do solo conduzido de forma inadequada, principalmente em atividades agropecuárias e silviculturais sem controle, associados aos fatores chuva, declividade e tipo de solo, aceleram a sua degradação (Santos et al., 2010). De forma geral, a erosão reduz a capacidade produtiva dos solos e aumenta o aporte de sedimentos e poluentes para os corpos de água (Merten \& Minella, 2003).

A bacia hidrográfica pode ser considerada como a área de drenagem que contém o conjunto de cursos d'água que convergem para esse rio, até a seção considerada, sendo, portanto, limitada em superfície a montante, pelos divisores de água, que correspondem aos pontos mais elevados do terreno e que separam bacias adjacentes (Vieira et al., 2012). Segundo Teodoro et al. (2007), cada bacia hidrográfica interliga-se com outra de ordem hierárquica superior, constituindo em relação à última, uma sub-bacia. Nesta perspectiva, a sub-bacia do Córrego do Guanabara, situada no município de Reserva do Cabaçal, é uma das unidades hidrográficas da Bacia do Alto Paraguai - BAP, em que está contido o Pantanal Mato-grossense.

Atualmente, para análises ambientais, os Sistemas de Informação Geográfica (SIG) são ferramentas eficientes devido a sua grande versatilidade na gestão e análise de informações espaciais. Assim, Felgueiras (2001) relatou que os SIGs assumem um papel fundamental e necessário como ferramenta básica para o planejamento e gestão de recursos naturais. Os procedimentos operacionais para a modelagem da vulnerabilidade ambiental, neste caso do risco de degradação do solo por erosão, exigem informações espacializadas de relevo, em termos de dissecação ou declividade; erodibilidade do solo e, uso da terra e cobertura vegetal. Essas informações ao serem analisadas de forma integrada, geram um produto síntese que expressa os diferentes graus de fragilidade que o ambiente possui em função de suas características genéticas (Cabral et al., 2011).

De acordo com Oliveira et al. (2008), o planejamento ambiental em bacias hidrográficas torna-se extremamente importante, pois atua como instrumento para minimizar a ação de impactos ambientais decorrentes da ação antrópica, possibilitando ao poder público a tomada de decisão para fins de conservação ambiental.

A identificação do potencial erosivo do solo poderá servir de base para a avaliação da vulnerabilidade ambiental de um dado local. Diante do exposto, o estudo objetivou avaliar a vulnerabilidade ambiental por erosão hídrica da sub-bacia do Córrego do Guanabara, no município de Reserva do Cabaçal - MT.

\section{MATERIAL E MÉTODOS}

\section{Localização da área de investigação}

Este estudo foi realizado na sub-bacia do Córrego do Guanabara, situada entre as latitudes $15^{\circ} 02^{\prime} 00^{\prime \prime} \mathrm{S}$ e $15^{\circ} 7^{\prime} 00^{\prime} \mathrm{S}$ e nas longitudes $58^{\circ} 28^{\prime} 30^{\prime \prime} \mathrm{W}$ e $58^{\circ} 25^{\prime} 00^{\prime \prime} \mathrm{W}$, no município de Reserva do Cabaçal, na região sudoeste de planejamento do estado de Mato Grosso (Figura 1).
O Córrego do Guanabara é um afluente do rio Cabaçal que deságua no rio Paraguai, principal curso hídrico formador do Bioma Pantanal. Desta forma, os sedimentos oriundos da bacia de estudo são carreados para o bioma, cuja extensão, além de ocupar terras do território brasileiro estende-se às da Bolívia e Paraguai. 


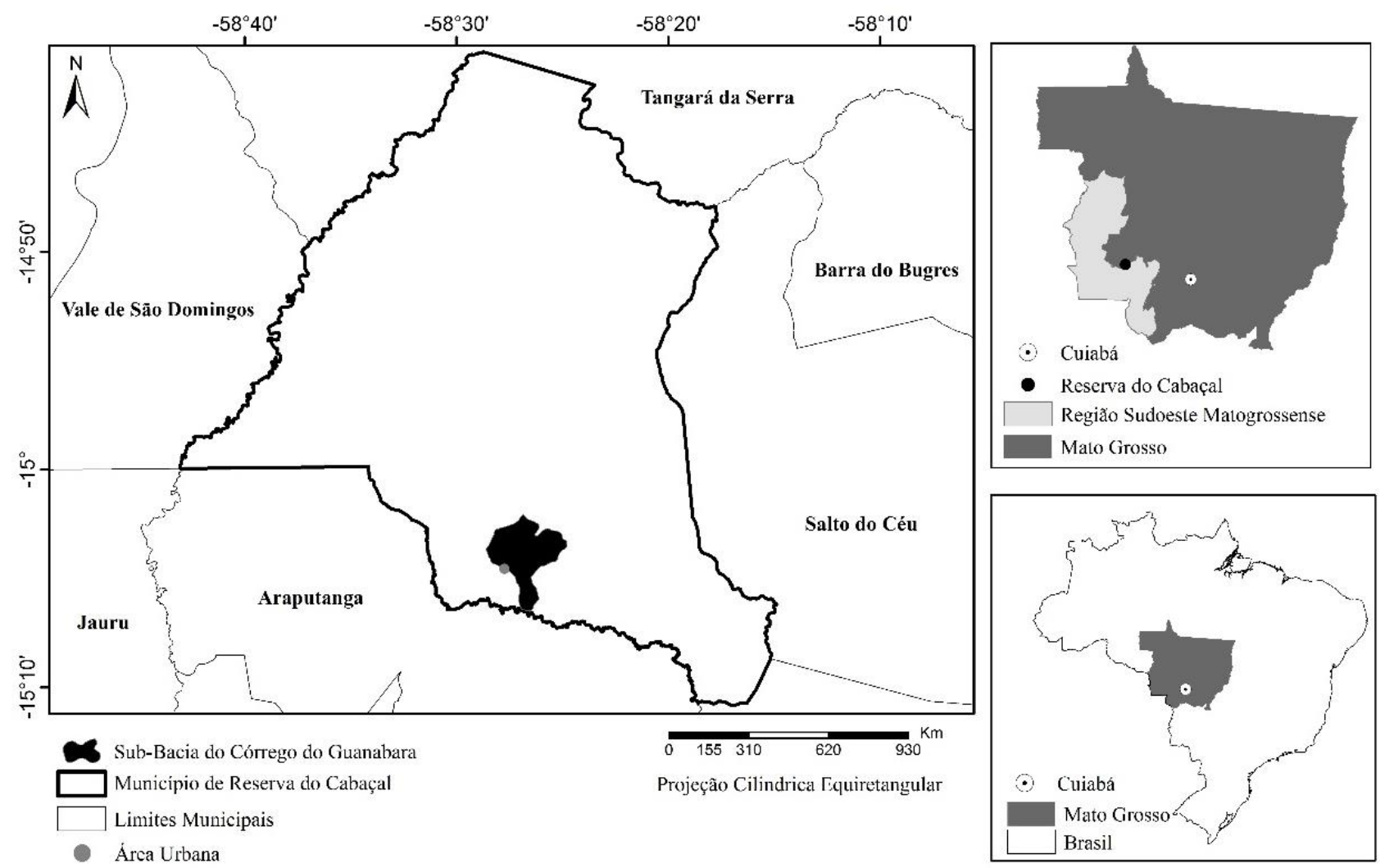

Figura 1. Mapa de localização e situação da Sub-bacia do Córrego do Guanabara no município de Reserva do Cabaçal-MT.

A população do município de Reserva do Cabaçal em 2010 era de 2.572 habitantes, distribuída numa área territorial de 1.337,041 $\mathrm{km}^{2} \quad$ (IBGE, 2013). Seu Índice de Desenvolvimento Humano Municipal (IDH-M) em 2010 foi de 0,676, abaixo da média do Estado que é de 0,725 (PNUD, 2013). Em sua extensão territorial é desenvolvida a pecuária (leite e corte) sendo esta a principal atividade econômica, além do potencial para o turismo.

\section{Procedimentos metodológicos}

Os mapeamentos de interesse do estudo em formato vetorial foram obtidos junto a SEPLAN/MT, SEMA/MT, IBGE, INPE, ANA e projeto Radambrasil (Brasil, 1982). Estes foram compilados, compatibilizados e organizadas as suas informações no Banco de Dados Geográficos - BDG implementado no Sistema de Informações Geográficas ArcGis (Esri, 2008).

A compartimentação morfopedológica da área foi realizada por meio da associação dos mapas de geomorfologia e pedologia da área de estudo em ambiente SIG. A definição de cada compartimento variou de acordo com as características físicas analisadas em conjunto.
A avaliação da susceptibilidade à erosão hídrica foi obtida por meio da associação de informação das classes de erodibilidade sugeridas por Salomão (2010) de acordo com os tipos de solos representado no mapa de pedologia (Mato Grosso, 2007).

A combinação do mapa de erodibilidade com o do fator topográfico (LS), no programa ArcGis, versão 9.2, resultou no mapa de susceptibilidade à erosão hídrica. As definições das classes de susceptibilidade à erosão, com base no percentual de declive, seguiram os critérios do IPT (1990).

O mapa do fator topográfico (LS) corresponde ao mapa de isodeclividades de Salomão (2010) e foi obtido por meio do Modelo Digital de Elevação (MDE), gerado a partir das imagens do radar interferométrico (SRTM - Missão Topográfica Radar Shuttle), banda C, com resolução espacial de 30 x 30m, de 2004; obtidas gratuitamente no projeto Topodata no sitio do Instituto Nacional de pesquisas Espaciais - INPE. O processamento digital das cenas incluiu: geração de mosaico, verificação da ocorrência dos valores de altitude e inexistência de valores (buracos) e conversão de projeção (Nunes et al., 2013). 
A partir das imagens de radar tratadas e das técnicas computacionais foram gerados os mapas clinográficos (declividade) e de direção de fluxo. Esses mapas foram reclassificados e combinados de modo a gerar o mapa de rampas homogêneas, de onde foram extraídos os valores de declividade média de rampa e de altura de rampa (Fornelos \& Neves, 2007).

$\mathrm{O}$ potencial à erosão laminar, pode assim ser definido como resultado da interação entre susceptibilidade à erosão laminar dos terrenos em desenvolver erosão e o uso atual da terra (Silva Neto \& Nunes, 2011). Para obtenção do mapa do potencial à erosão hídrica foram combinados em SIG o mapa de susceptibilidade à erosão com o de uso atual da terra, considerando as classes de uso sugeridas por Salomão (2010):
Classe I: alto potencial - uso atual do solo incompatível com a susceptibilidade à erosão hídrica laminar;

Classe II: médio potencial - uso atual do solo incompatível com a susceptibilidade à erosão hídrica laminar, possível de ser controlada com práticas conservacionistas adequadas;

Classe III: baixo potencial - uso atual do solo compatível com a susceptibilidade à erosão hídrica laminar.

Os parâmetros para o estabelecimento do potencial à erosão hídrica foram analisados conforme o Quadro 1, assim definindo as classes do potencial atual à erosão.

Os arquivos dos mapas gerados foram submetidos à correção por meio das informações obtidas em campo e após, no ArcGis, foram elaborados os layouts e as quantificações.

Quadro 1. Classes de potencial à erosão hídrica conforme a susceptibilidade do solo à erosão hídrica e as classes de uso atual da terra.

\begin{tabular}{|c|c|c|c|c|c|}
\hline \multirow[b]{2}{*}{$\begin{array}{l}\text { Susceptibilidade } \\
\text { à erosão hídrica }\end{array}$} & \multicolumn{5}{|c|}{ Classes de uso atual da terra } \\
\hline & $\begin{array}{c}\text { I } \\
\text { Intensa } \\
\text { atividade } \\
\text { antrópica }\end{array}$ & $\begin{array}{c}\text { II } \\
\text { Moderada } \\
\text { atividade } \\
\text { antrópica }\end{array}$ & $\begin{array}{c}\text { III } \\
\text { Muito } \\
\text { reduzida } \\
\text { atividade } \\
\text { antrópica - } \\
\text { vegetação de } \\
\text { baixo e médio } \\
\text { porte }\end{array}$ & $\begin{array}{c}\text { IV } \\
\text { Muito reduzida } \\
\text { atividade } \\
\text { antrópica - } \\
\text { vegetação de } \\
\text { alto a médio } \\
\text { porte }\end{array}$ & $\begin{array}{c}\mathrm{V} \\
\text { Espelho } \\
\text { s } \\
\text { d'água } \\
\text { e } \\
\text { várzeas }\end{array}$ \\
\hline $\begin{array}{l}\text { I (Extremamente } \\
\text { susceptível) }\end{array}$ & I & $\mathrm{I}$ & I & II & - \\
\hline II (Muito susceptível) & I & II & II & III & - \\
\hline $\begin{array}{l}\text { III (Moderadamente } \\
\text { susceptível) }\end{array}$ & II & II & II & III & - \\
\hline $\begin{array}{l}\text { IV (Pouco } \\
\text { susceptível) }\end{array}$ & II & III & III & III & - \\
\hline $\begin{array}{l}\text { V (Pouco a não } \\
\text { susceptível) }\end{array}$ & III & III & III & III & III \\
\hline
\end{tabular}

Nos trabalhos de campo, além da validação dos mapas, foram coletadas amostras deformadas e indeformadas, nas camadas de 0,0 a $0,1 \mathrm{~m}$ e 0,1 a $0,2 \mathrm{~m}$, para as análises de granulometria (textura do solo) e densidade do solo. Para as análises de agregados do solo, as coletas foram realizadas na camada de 0,0 $0,1 \mathrm{~m}$.

Foram coletadas amostras em solos pertencentes ao grupo dos Neossolos, os quais demonstraram ser o tipo de solo predominante na área de estudo. $\mathrm{O}$ estudo foi realizado nos seguintes ambientes: área degradada, onde se observou processo visível de erosão hídrica (voçorocas); área moderadamente degradada, processo inicial de erosão hídrica, sulcos e entressulcos (laminar); e áreas conservadas, inseridas em áreas de mata nativa, onde sofreram pouca ou nenhuma ação antrópica, 
sem processo visível de erosão hídrica (Souza et al., 2013).

A análise granulométrica e a densidade do solo foram determinadas conforme descrito em Donagema et al. (2011).

Foram coletadas amostras deformadas de solo para a determinação da estabilidade de agregados. Essas amostras foram coletadas em torrões, armazenadas em potes plásticos e levadas para o laboratório, onde foram destorroadas manualmente, de acordo com a fraqueza natural e tamisadas em peneira com abertura de malha 9,51 mm e, após, foram secas ao ar e à sombra. $\mathrm{O}$ solo seco foi posto para pré-umedecimento por capilaridade por um período de 2 horas. Após, as amostras foram colocadas sobre um conjunto de peneiras com diâmetros de malha de 4,75;2,00;1,00;0,50 e $0,25 \mathrm{~mm}$, respectivamente. $\mathrm{O}$ conjunto de peneiras foi colocado em um agitador vertical, semelhante ao proposto por Yoder (1936), com 28 oscilações por minuto e posto a agitar em água por um período de 10 minutos. O solo retido em cada classe foi seco em estufa a $105^{\circ}$ C por 24 horas e posteriormente pesado, sem descontar o material inerte presente na massa de agregados.

A partir dos dados obtidos foi determinada a estabilidade de agregados, representada pela distribuição de agregados estáveis em água em diferentes classes de diâmetros, segundo metodologia de Van Bavel (1949), diâmetro médio ponderado (DMP) e diâmetro médio geométrico (DMG), conforme descrito por Kemper \& Rosenau (1986).

Quatro amostras pontuais de Neossolos Quartzarênicos, compostas de 3 sub-amostras foram coletadas e posteriormente agrupadas em uma amostra composta. A análise estatística foi realizada por meio do programa ASSISTAT, versão 7,7 Beta (Silva \& Azevedo, 2002), em delineamento inteiramente casualizado e teste de Tukey com nível de confiança de 5\%.

\section{RESULTADOS E DISCUSSÃO}

Segundo Hermuche et al. (2009), para o melhor entendimento da paisagem local, a compartimentação morfopedológica se torna fundamental, pois realiza uma análise comparativa e associativa dos condicionantes físicos (geomorfologia) comas classes de solos encontradas na área de estudo.
O compartimento morfopedológico que apresentou maior expressão na área de estudo foi o número 4, que é representado por Sistema Regional de Aplanamento $2+$ Neossolos Quartzarênicos e o segundo com maior representação na área foi o número 1, composto por Sistema Regional em Colinas e Morros + Argissolos (Tabela 1).

Tabela 1. Descrição e representatividade dos compartimentos da sub-bacia do Córrego do Guanabara.

\begin{tabular}{|c|c|c|c|}
\hline Compartimentos & Morfopedologia & $\begin{array}{r}\text { Área } \\
\text { (ha) }\end{array}$ & $\begin{array}{r}\text { Área } \\
(\%)\end{array}$ \\
\hline 1 & $\begin{array}{l}\text { Sistema Regional em Colinas e Morros } \\
+ \text { Argissolos Vermelho Distrófico }\end{array}$ & 869,33 & 33,54 \\
\hline 2 & $\begin{array}{l}\text { Sistema regional de Aplanamento } 2+ \\
\text { Argissolos Vermelho Distrófico }\end{array}$ & 113,97 & 4,40 \\
\hline 3 & $\begin{array}{l}\text { Sistema de Dissecação em Colinas e } \\
\text { Morros + Neossolos Quartzarênicos }\end{array}$ & 285,23 & 11,01 \\
\hline 4 & $\begin{array}{l}\text { Sistema regional de Aplanamento } 2+ \\
\text { Neossolos Quartzarênicos }\end{array}$ & 1323,25 & 51,05 \\
\hline Total & & 2591,78 & 100 \\
\hline
\end{tabular}

Os compartimentos 1 e 2 (Figura 2) são compostos por Argissolos Vermelhos Distróficos. Segundo Embrapa (2006), esta classe apresenta grupamento de solos com B textural, com argila de atividade baixa ou alta conjugada com saturação por bases baixa ou caráter alítico. Segundo Prado (2011), citado por Melo (2014), os argissolos são susceptíveis a erosão devido à rápida infiltração no horizonte superficial (A), onde o teor de argila 
é baixo, e uma lenta infiltração nos horizontes subjacentes $(\mathrm{Bt})$ por apresentar gradiente textural, ou seja, maior teor de argila, por isso o excesso de água que não infiltra escoa superficialmente. $\mathrm{Na}$ área de estudo há predominância de Neossolos Quartzarênicos (Figura 3), os quais correspondem a 62,06\% da área total, compreendendo solos constituídos por material mineral, ou por material orgânico pouco espesso, que não apresentem alterações expressivas em relação ao material originário devido à baixa intensidade de atuação dos processos pedogenéticos, seja em razão de características inerentes ao próprio material de origem, como maior resistência ao intemperismo ou composição químicomineralógica, ou por influência dos demais fatores de formação (clima, relevo ou tempo), que podem impedir ou limitar a evolução dos solos (EMBRAPA, 2006).

$\mathrm{Na}$ bacia de estudo foram encontradas áreas com processo erosivo muito acentuado, que segundo Araújo et al. (2013), ocorre pelo fato desses solos serem muito arenosos, com baixa capacidade de agregação de partículas, devido aos baixos teores de matéria orgânica e argila.

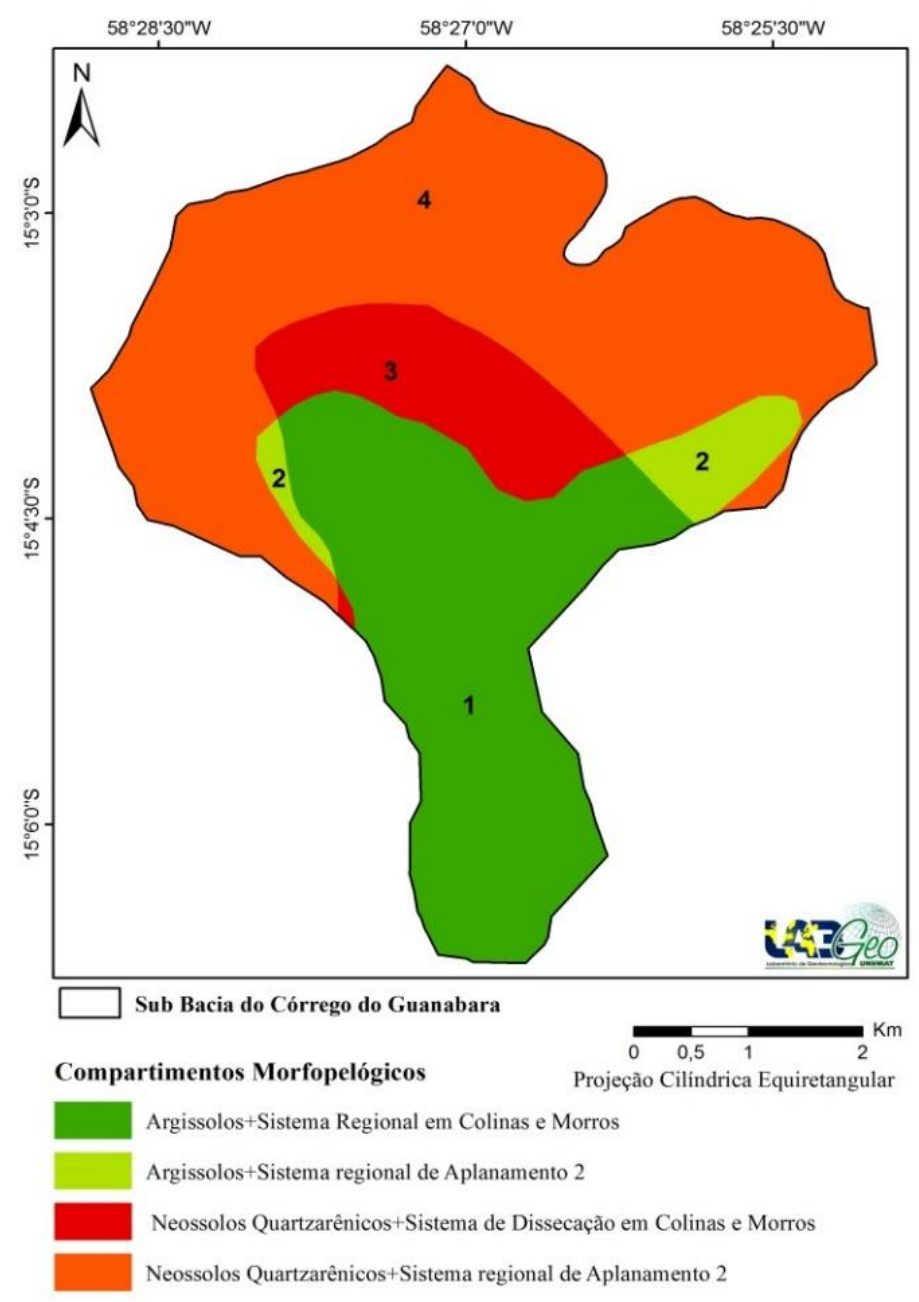

Figura 2. Mapa de compartimentos morfopedológicos da sub-bacia do córrego do Guanabara.

Conforme Fernandes (2011), a erodibilidade pode ser definida como a maior ou menor facilidade com que as partículas do solo são destacadas e transportadas pela ação de um agente erosivo, ou seja, indica a resistência do solo ao impacto das chuvas. Na bacia ocorrem dois graus de erodibilidade: muito alta e média, com $62,06 \%$ e $37,94 \%$, respectivamente. Este resultado pode ser função do elevado teor de areia presente nos Neossolos, o que incorre em pouca ou nenhuma agregação, acelerando os processos erosivos. 


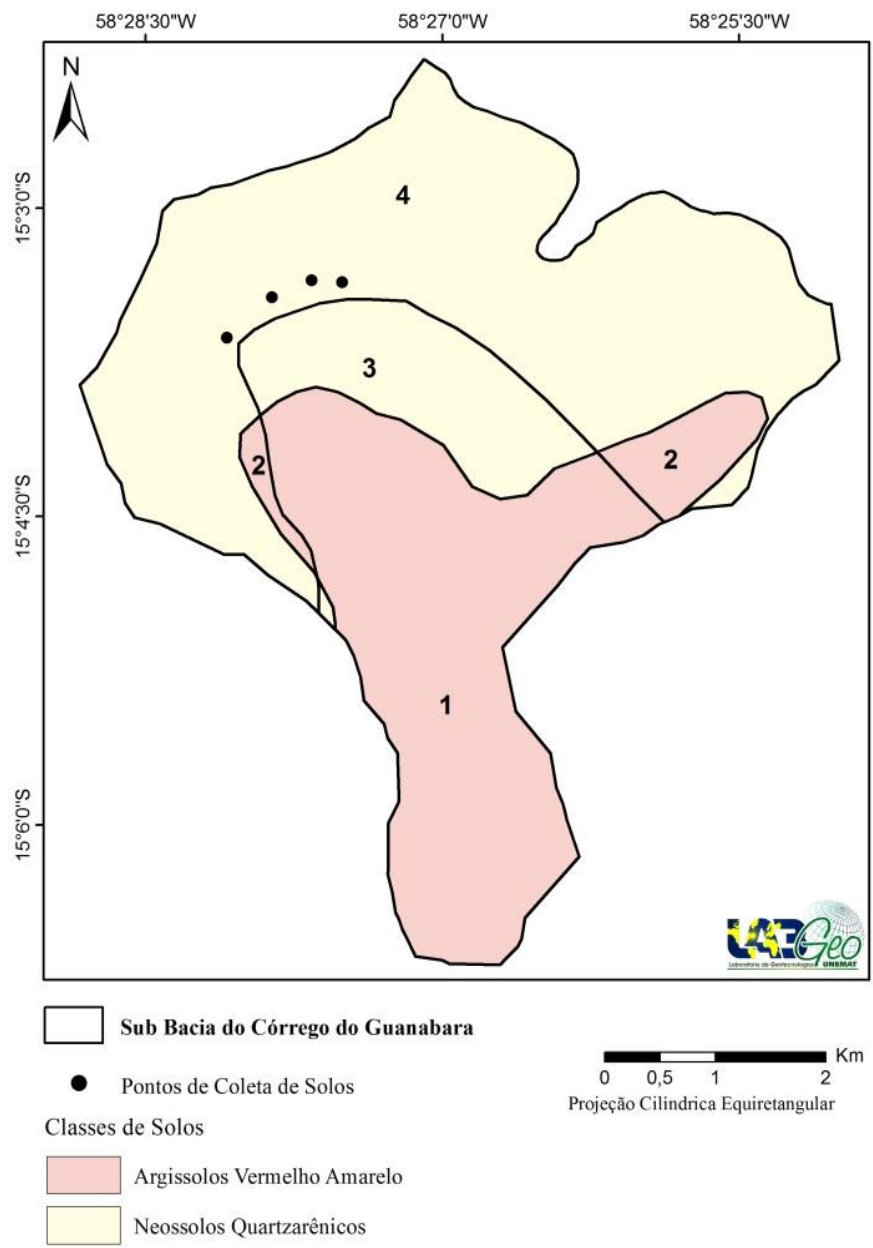

Figura 3. Mapa de solos dos compartimentos morfopedológicos da sub-bacia do córrego do Guanabara.

As áreas com grau de erodibilidade muito alto são recobertas pelos Neossolos Quartzarênicos e as áreas que apresentam médio grau de erodibilidade pelos Argissolos Vermelho-Amarelo, o que indica que a área de estudo se encontra em elevado grau de erodibilidade (Figura 4).

O tipo do solo e o grau de declividade do terreno, associados ao uso da terra numa bacia hidrográfica, podem determinar o surgimento de vários tipos de processos erosivos (Sala \& Gaspareto, 2010). A declividade apresentou pequena influência nesses processos erosivos visto que a área apresenta 69,39\% da sua área situada em relevo plano e suave ondulado (Figura 5). O alto grau de erodibilidade está associado ao tipo e à textura dos solos, os quais apresentam grande quantidade de areia, havendo pouca influência do relevo.

O mapa de susceptibilidade à erosão hídrica (Figura 6) evidenciou que $61,06 \%$ da extensão territorial da Sub-bacia são extremamente susceptíveis à erosão hídrica, 27,88\% muito susceptíveis e $10,06 \%$ moderadamente susceptíveis. Portanto, todos os compartimentos encontrados na área apresentam extremamente, muito e moderada susceptibilidade à erosão.

As classes de potencial atual à erosão hídrica indicam que existe moderada atividade antrópica em áreas de médio potencial à erosão e estas são muito susceptíveis à erosão (Figura 7). A atuação do homem na unidade hidrográfica de maneira imprópria vem contribuindo a aceleração de processos erosivos, os quais causam prejuízos na maioria das vezes irreparáveis a natureza, acarretando deterioração das características, químicas, físicas e biológicas do solo. Araújo et al. (2009) relatam que a preocupação em conciliar desenvolvimento econômico e conservação ambiental, nas últimas décadas, fizeram crescer a demanda por projetos, planos e estratégias que integrem diferentes agentes físicos, econômicos e sociais que atuam no meio, em vista da intensa modificação e degradação ambiental gerada pelo homem. 


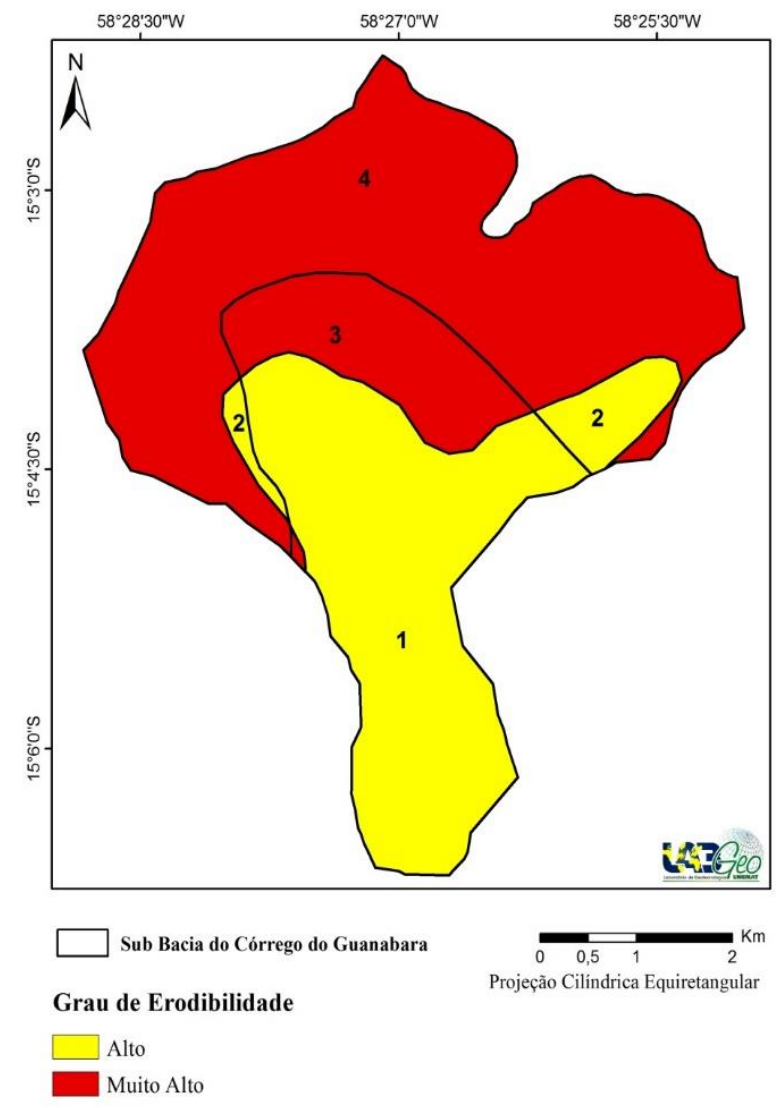

Figura 4. Mapa dos graus de erodibilidade do solo dos compartimentos morfopedológicos da sub-bacia do Córrego do Guanabara.

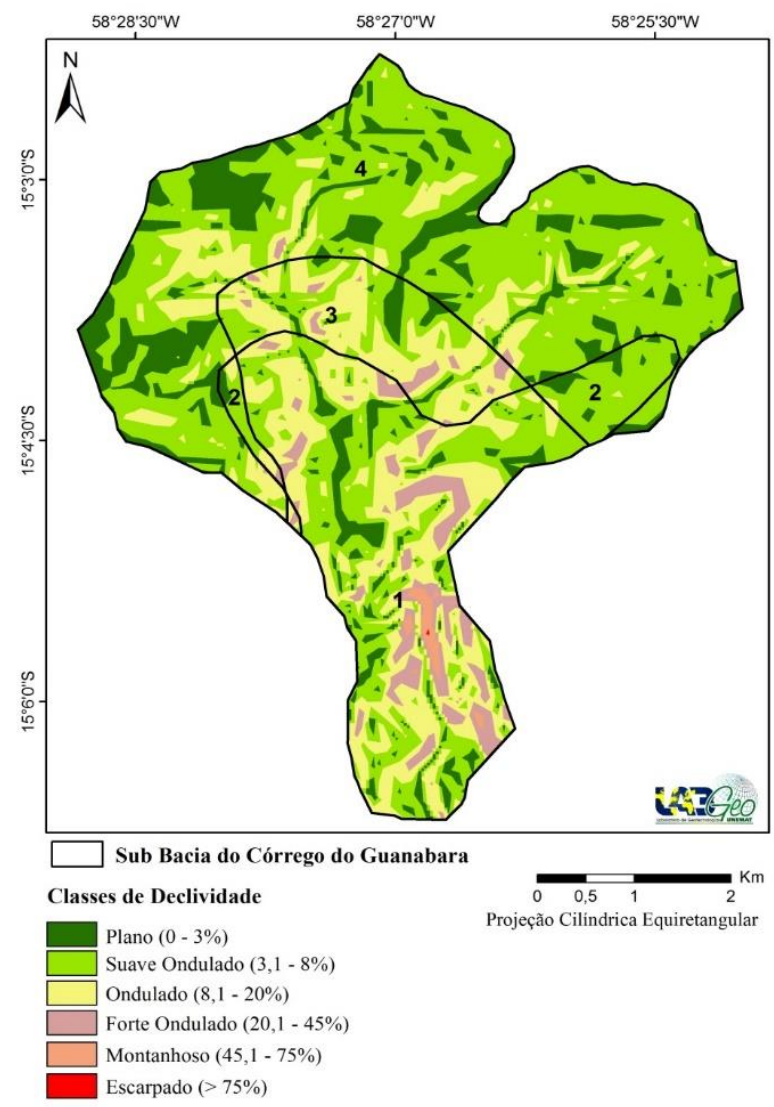

Figura 5. Mapa de classes de declividade dos compartimentos morfopedológicos da sub-bacia do Córrego do Guanabara. 
Na sub-bacia do Córrego do Guanabara, quando o solo se apresentar extremamente susceptível à erosão (Figura 6) o potencial à erosão hídrica será médio a alto (Figura 7). O mapa de potencial à erosão hídrica (Figura 7) indica que os locais de alto e médio potencial são compostos por Argissolos e Neossolos, os quais são extremamente e moderadamente susceptíveis à erosão hídrica (Figura 6), situados sobre um relevo plano e suave ondulado (Figura 5) os quais foram submetidos a atividades antrópicas inadequadas a sua capacidade de uso. Resultados encontrados por Vale Junior et al. (2009), ao estudar Neossolos Quartzarênicos, sob plantio de Acacia mangium, evidenciaram também que esta classe de solo possui susceptibilidade a erosão muito elevada, tendendo a perder grande quantidade de solo por erosão.

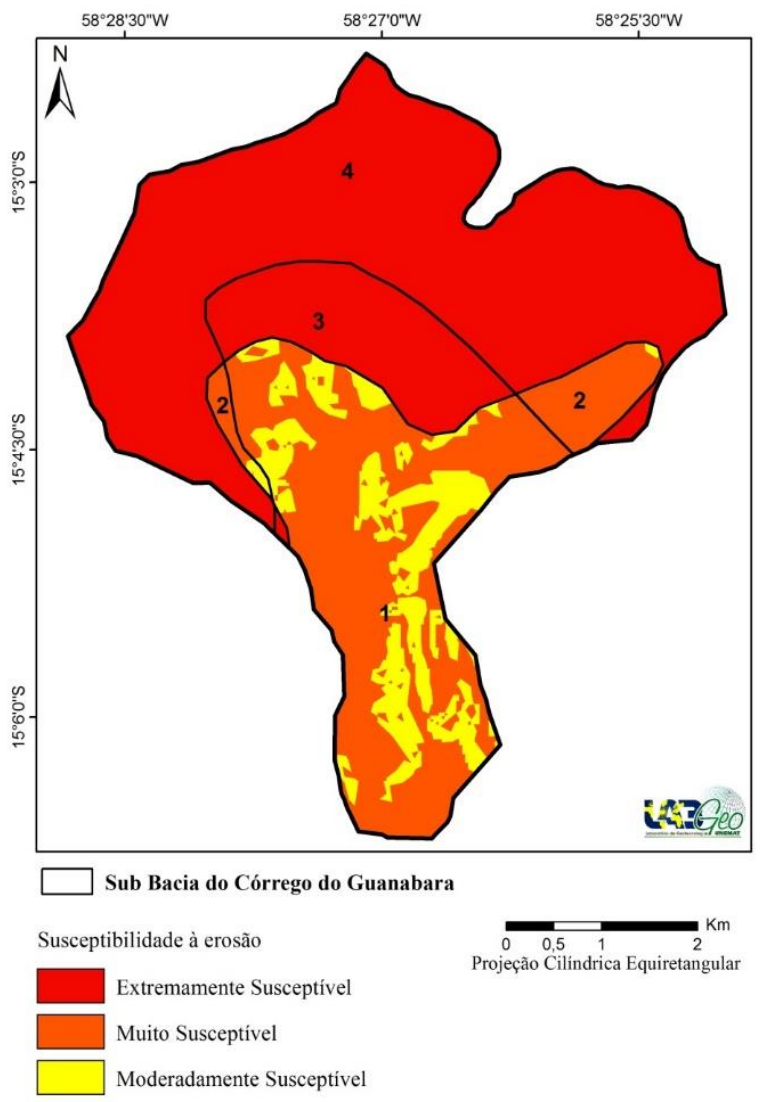

Figura 6. Mapa de susceptibilidade à erosão hídrica da sub-bacia do Córrego do Guanabara.

O uso da terra de maneira não conservacionista traz inúmeros impactos ao ambiente, envolvendo redução da biodiversidade, degradação dos solos, assoreamento dos cursos hídricos, entre outras. Em estudo realizado por Ramos et al. (2011), foi verificado que o uso de práticas conservacionistas, como manutenção da cobertura vegetal, gerou resultados significativos e positivos quanto à diminuição do salpicamento de partículas do solo.

Henrique \& Fernandes (2012) ressaltam a importância de atributos físicos do solo, como textura, porosidade, estrutura, permeabilidade e atributos químicos, visto que estes podem influenciar na maior ou menor susceptibilidade aos processos erosivos.

Vitte \& Mello (2007) destacam que os processos erosivos são influenciados pelas propriedades do solo, assim como a distribuição do tamanho das partículas, estabilidade estrutural, conteúdo de matéria orgânica, natureza dos minerais de argila e constituintes químicos. Considerando a importância dos atributos do solo nos processos erosivos, os trabalhos de campo se tornam indispensáveis para o adequado conhecimento do comportamento dos solos, bem como para a validação do modelo de vulnerabilidade ambiental adotado. 


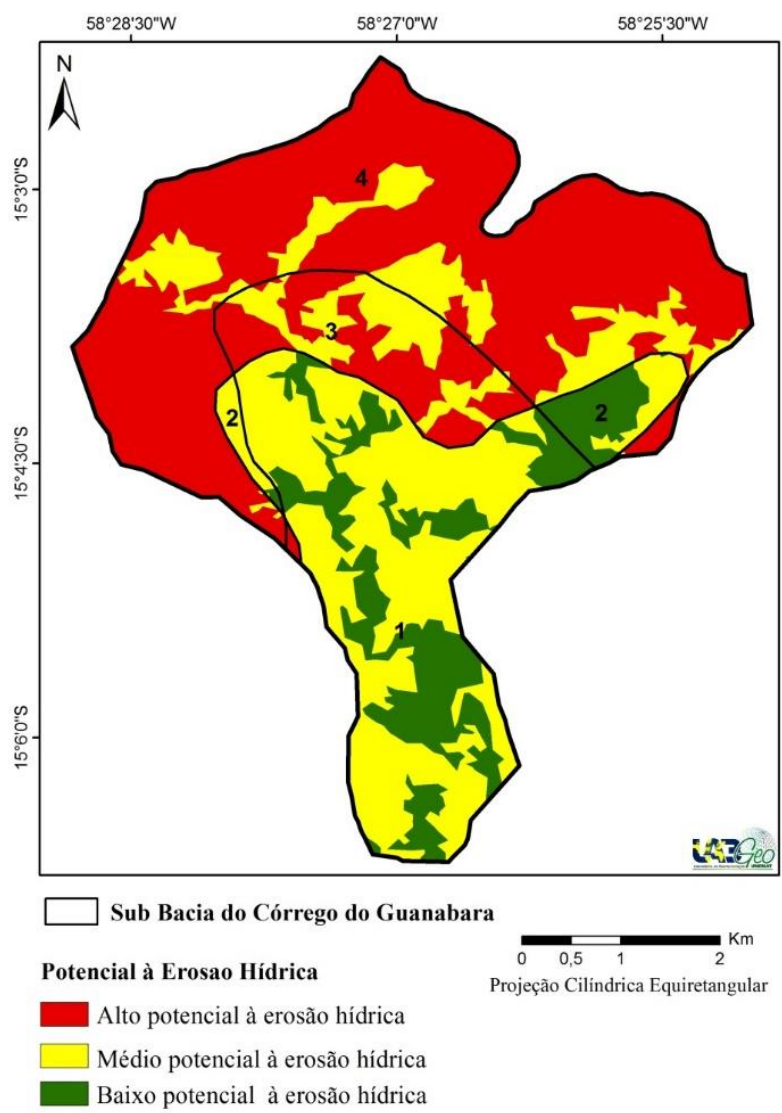

Figura 7. Mapa de distribuição do potencial atual à erosão hídrica da sub-bacia do Córrego do Guanabara.

Na Tabela 2 são exibidos os atributos granulométricos da camada de $0,0-0,1 \mathrm{~m}$, em três ambientes na sub-bacia do Córrego do Guanabara, conforme os pontos de coleta (Figura 03). Segundo Correchel (2003), a textura é um dos fatores de caráter físico que influi na maior ou menor quantidade de solos arrastados pela erosão. Pode-se observar que não houve diferença estatística significativa entre os atributos areia, silte e argila na camada de 0,0 a $0,1 \mathrm{~m}$ nos ambientes estudados, porém houve predominância da fração areia, o que é característico de um Neossolo Quartzarênico, considerado um solo raso e susceptível a erosão.

Tabela 2. Granulometria do solo nos ambientes natural, moderadamente degradado e degradado, na camada de $0,0-0,1 \mathrm{~m}$.

\begin{tabular}{crrr}
\hline & \multicolumn{3}{c}{ Granulometria $\left(\mathbf{g ~ k g}^{-1} \mathbf{)}\right.$} \\
\cline { 2 - 4 } Fração & \multicolumn{3}{c}{ Ambiente } \\
\cline { 2 - 4 } & Natural & $\begin{array}{c}\text { Moderadamente } \\
\text { Degradado }\end{array}$ & Degradado \\
\hline Areia & $951,07 \mathrm{a}$ & $950,35 \mathrm{a}$ & $948,82 \mathrm{a}$ \\
Silte & $11,32 \mathrm{a}$ & $18,96 \mathrm{a}$ & $19,30 \mathrm{a}$ \\
Argila & $37,61 \mathrm{a}$ & $30,68 \mathrm{a}$ & $31,87 \mathrm{a}$ \\
\hline
\end{tabular}

Médias seguidas pela mesma letra na linha não diferem estatisticamente entre si pelo teste de Tukey ao nível de $5 \%$ de probabilidade.

$\mathrm{Na}$ camada de 0,1 a $0,2 \mathrm{~m}$ os solos apresentaram comportamento parecido ao da camada de 0,0 a $0,1 \mathrm{~m}$, a não ser o caso da argila que nos ambientes natural e moderadamente degradado (Tabela 3), diferenciaram estatisticamente, sendo que no ambiente degradado houve maior concentração de argila. Fato este que pode ser explicado pelo carreamento da argila, por ser uma fração mais fina e mais leve, o que facilita o seu transporte.

Tabela 3. Granulometria do solo nos ambientes natural, moderadamente degradado e degradado, na camada de 0,1 $0,2 \mathrm{~m} \mathrm{em} \mathrm{g} \mathrm{kg}^{-1}$. 


\begin{tabular}{crrr}
\hline & \multicolumn{3}{c}{ Ambientes } \\
\cline { 2 - 4 } Fração & Natural & $\begin{array}{c}\text { Moderadamente } \\
\text { Degradado }\end{array}$ & Degradado \\
\hline Areia & $940,61 \mathrm{a}$ & $952,87 \mathrm{a}$ & $949,11 \mathrm{a}$ \\
Silte & $21,01 \mathrm{a}$ & $21,37 \mathrm{a}$ & $17,39 \mathrm{a}$ \\
Argila & $38,38 \mathrm{a}$ & $25,75 \mathrm{~b}$ & $33,50 \mathrm{ab}$ \\
\hline
\end{tabular}

Médias seguidas pela mesma letra na linha não diferem estatisticamente entre si pelo teste de Tukey ao nível de $5 \%$ de probabilidade.

O ambiente natural apresentou maior proporção de macroagregados em relação aos ambientes moderadamente degradado e degradado (Tabela 4), este fato evidencia que o uso e o manejo dado aos solos da região estão levando à menor estabilidade dos agregados, predispondo o solo à degradação.

Tabela 4. Distribuição do percentual de macro e microagregados estáveis em água, diâmetro médio ponderado (DMP) e diâmetro médio geométrico (DMG) do solo, nos ambientes natural, moderadamente degradado e degradado, na camada de $0,0-0,1 \mathrm{~m}$

\begin{tabular}{cccr}
\hline \multirow{2}{*}{ Atributos } & Natural & $\begin{array}{c}\text { Moderadamente } \\
\text { Degradado }\end{array}$ & Degradado \\
\cline { 2 - 4 } & Macroagregados $(0,250-9,51 \mathrm{~mm} \backslash$ \\
$(\%)$ & $39,63 \mathrm{a}$ & $34,00 \mathrm{~b}$ & $26,37 \mathrm{c}$ \\
Microagregados $(<0,250 \mathrm{~mm})$ & $27,13 \mathrm{c}$ & $32,67 \mathrm{~b}$ & $40,20 \mathrm{a}$ \\
$(\%)$ & $1,59 \mathrm{a}$ & $1,49 \mathrm{a}$ & $1,05 \mathrm{~b}$ \\
DMP $(\mathrm{mm})$ & $0,64 \mathrm{a}$ & $0,54 \mathrm{~b}$ & $0,40 \mathrm{c}$ \\
DMG $(\mathrm{mm})$ & & &
\end{tabular}

Médias seguidas pela mesma letra na linha não diferem estatisticamente entre si pelo teste de Tukey ao nível de $5 \%$ de probabilidade.

Em relação aos microagregados, todos os ambientes se diferenciaram estatisticamente, sendo que o ambiente degradado apresentou os maiores valores. Possivelmente devido à ausência de material cimentante, pois nesta área observou-se a ausência de matéria orgânica, que constitui um dos principais elementos que contribuem para agregação do solo.

Ao analisar o DMP, o ambiente que divergiu dos demais foi o degradado, o qual apresentou os menores valores. Silva et al. (2000) expõem que quanto maior for o agregado maior será o seu DMP e os espaços porosos entre eles, aumentando a infiltração da água ao longo do perfil e diminuindo a erosão. Comportamento este que foi observado nos ambientes moderadamente degradado e natural, no caso do degradado o seu DMP foi menor, devido ao estado de elevada degradação no qual se encontrava.

A área natural apresentou os maiores valores para DMG, o que se deve provavelmente à presença de maior grau de estruturação deste solo, juntamente com a presença das raízes que liberam exsudatos, elevando os teores de matéria orgânica do solo por meio da ciclagem bioquímica, contribuindo assim para a estabilidade de agregados. Resultado distintos foram encontrados por Junqueira et al. (2010) ao investigarem Neossolos Quartzarênicos no município de Baliza/GO, em que verificaram maior índice de estabilidade deste solo sob pastagem quando comparado à mata, mesmo assim esta estabilidade não foi suficiente para conter os processos erosivos.

A densidade do solo pode interferir na ação dos processos erosivos, pois está relacionada à maior ou menor compactação dos solos, ou seja, quanto maior a densidade, maior a dificuldade da água se infiltrar no solo, aumentando o escoamento superficial (Guerra \& Botelho, 1996) e, consequentemente, a energia disponível para a desagregação e transporte das partículas. Neste estudo, a densidade do solo apresentou o mesmo comportamento nas diferentes profundidades em relação ao ambiente moderadamente degradado e degradado (Tabela 5). 
Tabela 5. Densidade do solo nos ambientes natural, moderadamente degradado e degradado, nas camadas de 0,0 - 0,1 e $0,1-0,2 \mathrm{~m}$.

\begin{tabular}{cccc}
\hline Camada (m) & \multicolumn{3}{c}{ Densidade do Solo $\left(\mathbf{g ~ c m}^{-3}\right)$} \\
\hline & Natural & $\begin{array}{c}\text { Moderadamente } \\
\text { Degradado }\end{array}$ & $\begin{array}{c}\text { Degrada } \\
\text { do }\end{array}$ \\
\hline $0,00-0,10$ & $1,33 \mathrm{~b}$ & $1,58 \mathrm{a}$ & $1,59 \mathrm{a}$ \\
$0,10-0,20$ & $1,50 \mathrm{~b}$ & $1,60 \mathrm{a}$ & $1,56 \mathrm{a}$ \\
\hline
\end{tabular}

Médias seguidas pela mesma letra na linha não diferem estatisticamente entre si pelo teste de Tukey ao nível de $5 \%$ de probabilidade.

$\mathrm{O}$ ambiente natural se diferenciou dos demais por apresentar os menores valores de densidade, possivelmente devido à maior presença de matéria orgânica nesse ambiente, contribuindo para a melhor aeração e aumento da porosidade desse solo. A maior densidade nos ambientes degradado e moderadamente degradado pode ser devida ao trânsito excessivo e sem controle de animais nessas áreas. Nesse sentido, Leão et al. (2004) destacam como consequência do pisoteio animal excessivo a compactação do solo, caracterizada pelo aumento da densidade do solo como resultado de cargas ou pressões aplicadas. Assim dificultando a fixação do sistema radicular e estabelecimento da pastagem na área. Esses resultados corroboram com os apresentados por Sales et al. (2010), os quais verificaram que, independente da camada ou da época de amostragem, todas as áreas sob interferência antrópica (áreas de agricultura e pecuária), apresentaram incremento na densidade do solo.

Os processos erosivos iniciam quando há o impacto das gotas de água da chuva sobre o solo descoberto, sendo, portanto, necessário a manutenção da cobertura vegetal morta ou viva sobre o solo para sua proteção, evitando a desagregação e perda de solo, minerais e matéria orgânica. Desta forma, o controle dos processos erosivos na área de estudo somente será possível se no manejo do solo for considerada a capacidade de uso da terra e a susceptibilidade do solo à erosão hídrica.

$\mathrm{O}$ uso da terra sem um planejamento adequado implica em seu empobrecimento e na baixa produtividade das culturas, o que resulta na diminuição do nível socioeconômico e tecnológico da população rural (Rampim et al., 2012). As informações obtidas neste trabalho e difundidas para a comunidade poderão fornecer subsídios a políticas conservacionistas locais, para a seleção de áreas prioritárias à conservação e/ou recuperação do solo e à tomada de decisões sobre o adequado uso e manejo do solo, visando o desenvolvimento sustentável da região.

\section{CONCLUSÕES}

Na sub-bacia do Córrego do Guanabara ocorre o predomínio de Neossolos Quartzarênicos, os quais apresentam erodibilidade muito alta, apesar de ocorrerem em áreas de relevo plano e suave ondulado.

Toda a extensão da área de estudo é extremamente e moderadamente susceptível à erosão hídrica. Os locais de alto e médio potencial à erosão são compostos por solos extremamente e moderadamente susceptíveis à erosão, submetidos a atividades antrópicas inadequadas. $\mathrm{O}$ alto potencial erosivo dos solos da sub-bacia investigada pode afetar a produtividade agropecuária local, visto que a pecuária é predominante, além de contaminar e assorear os cursos d'água.

A análise física dos solos demonstrou que o ambiente degradado, função do uso e manejo inadequado utilizado na pecuária local, apresentou menor estabilidade de agregados, representada por maior teor de microagregados, menor Diâmetro Médio Ponderado (DMP) e maior densidade do solo, o que poderá resultar em maior suscetibilidade à erosão hídrica. 
A análise de vulnerabilidade ambiental à erosão hídrica se torna importante, pois fornece informações sobre a maior ou menor susceptibilidade de um ambiente ser degradado, além de fornecer ferramentas para a adequada tomada de decisão sobre o adequado planejamento, uso e ocupação do solo.

\section{AGRADECIMENTOS}

Ao CNPq pela bolsa de Iniciação científica e ao projeto "Modelagem de indicadores ambientais para a definição de áreas prioritárias e estratégicas à recuperação de áreas degradadas da região sudoeste de Mato Grosso/MT", vinculado à sub-rede de estudos sociais, ambientais e de tecnologias para o sistema produtivo na região sudoeste mato-grossense - REDE ASA, financiada no âmbito do Edital MCT/CNPq/FNDCT/FAPs/MEC/CAPES/PRO-CENTRO-OESTE No 031/2010.

\section{REFERÊNCIAS}

1. ALVARENGA, M.I.N.; PAULA, M.B. Planejamento conservacionista em microbacias. Informe Agropecuário, Belo Horizonte, v. 21, p. 55-64, 2000.

2. AMARAL, R.; ROSS, J.L.S. As unidades ecodinâmicas na análise da fragilidade ambiental do parque estadual do Morro do Diabo e entorno, Teodoro Sampaio/SP. GEOUSP - Espaço e Tempo, n. 26, p. 59-78, 2009.

3. ARAÚJO, C.M.J.; SANTOS, A.B.; OLIVEIRA, J.P.; GOMES, M.V.; ALVES, R.R. Neossolo quartzarênico: área natural e meio antropizado no assentamento rural de Angical/BA. Anais XIV Encontro de Geógrafos da América Latina - EGAL.Lima-Perú, 2013.

4. ARAÚJO, L.E.; SOUSA, F.A.S.; MORAES NETO, J.M.; SOUTO, J.S.; REINALDO, L.R.L.R. Bacias hidrográficas e impactos ambientais. Qualitas Revista Eletrônica, v.8, n.1, p. 1$18,2009$.

5. BERTONI, J.; LOMBARDI NETO, F. Conservação do Solo. 9.ed. São Paulo: Ícone, 2014. 355p.

6. BRASIL. Ministério das Minas e Energia. Secretaria-Geral. Projeto Radambrasil. Folha SD 21 Cuiabá; geologia, geomorfologia, pedologia, vegetação e uso potencial da terra. Rio de Janeiro, 1982, 520p.

7. CABRAL, J.B.P.; ROCHA, I.R.; MARTINS, A.P.; ASSUNÇÃO, H.F.E.; BECEGATO, V.A. Mapeamento da fragilidade ambiental da bacia hidrográfica do Rio Doce (GO), utilizando técnicas de geoprocessamento. Revista Internacional de Ciencia y Tecnología de laInformación Geográfica, n. 11, p. 51-69, 2011.

8. CAMPOS, J.M.; NEVES, S.M.A.S. Cobertura vegetal e uso da terra na bacia hidrográfica do rio Paraguai/Jauquara-MT. In: II Jornada Cientifica da Unemat - Universidade do Estado de Mato Grosso, Cáceres, MT. 2009.

9. CAMPOS, L. P. Matéria Orgânica e qualidade física do solo em ambientes brasileiros. In: FERNANDES, C. (Coor.) Tópicos em física do solo. Funep, Jaboticabal-SP, 2012, 144p. 10. CORRECHEL, V. Avaliação de índices de erodibilidade do solo através da técnica da análise da redistribuição do "Fallout" $\mathrm{do}^{137}$ Cs. Tese Doutorado, Centro de Energia Nuclear na Agricultura. Universidade de São Paulo. 79p. São Paulo-SP, 2003.

11. COSTA JUNIOR, C.; PICCOLO M. DE C.; SIQUEIRA NETO, M. et al. Carbono total e $\delta 13 \mathrm{c}$ em agregados do solo sob vegetação nativa e pastagem no bioma Cerrado. Revista Brasileira de Ciência do Solo, Viçosa - MG, v. 35, n. 4, p. 1241-1252, 2011

12. CREPANI, E.; MEDEIROS, J. S.; HERNANDEZ, P. F.; FLORENZANO, T. G.; DUARTE, V.; BARBOSA, C. C. F. Sensoriamento remoto e geoprocessamento aplicados ao zoneamento ecológico-econômico e ao ordenamento territorial. 1. ed. São José dos Campos/SP: INPE, 2001. 124p.

13. D'ANDRÉA, A.F.; SILVA, M.L.N.; CURI, N. et al. Atributos de agregação indicadores da qualidade do solo em sistemas de manejo na região dos cerrados no sul do estado de Goiás. Revista Brasileira de Ciência do Solo, Viçosa - MG, v. 26, n. 4, p. 1047-1054, 2002.

14. DONAGEMA, G.K.; CAMPOS, D.V.B.; CALDERANO, S.B.; TEIXEIRA, W.G.; VIANA, J.H.M. (Org.). Manual de métodos de análise de solos. 2. ed. rev. 2011. Dados eletrônicos - Rio de Janeiro: Embrapa Solos,230p. Disponível em: <http://ainfo.cnptia.embrapa.br/digital/bitstream/item/104933/1/ Manual-de-Mtodos-de-Anilise-de-Solo.pdf $>$. Acesso em 06 Set 2013.

15. EMBRAPA. Centro Nacional de Pesquisas de solos. Sistema Brasileiro de Classificação de Solos. 2. ed. Rio de Janeiro: Embrapa, 2006. 306p.

16. EMPRESA BRASILEIRA DE PESQUISA AGROPECUÁRIA - EMBRAPA. Manual de métodos de análise de solo, 2. ed. Rio de Janeiro, 1997. 212p.

17. ENVIRONMENTAL SYSTEMS RESEARCH INSTITUTE (ESRI). ArcGIS Professional GIS for the desktop, versão 9.3. 2008.

18. FELGUEIRAS, C.A. Modelagem ambiental com tratamento de incertezas em sistemas de informação geográfica: O paradigma geoestatístico por indicação. Tese de Doutorado, Programa de Doutorado em Computação Aplicada. Instituto Nacional de Espaciais-INPE, 212p. São José dos Campos-SP, 2001.

19. FERNANDES, J.A. Estudo da Erodibilidade de Solos e Rochas de uma Voçoroca em São Valentim, RS. Dissertação de Mestrado em Engenharia Civil, Programa de Pós-Graduação em Engenharia Civil, Área de Concentração em Construção Civil e Preservação Ambiental, da Universidade Federal de Santa Maria- UFSM, 127p. Santa Maria - RS, 2011.

20. FORNELOS, L.F.; NEVES, S.M.A.S. Uso de modelos digitais de elevação (MDE) gerados a partir de imagens de radar interferométricos (SRTM) na estimativa de perdas de solo. Revista Brasileira de Cartografia, v. 59, n. 1, p. 25-33, 2007.

21. GUERRA, A.J.T.; BOTELHO, R.G.M. Características e Propriedades dos Solos relevantes para os estudos Pedológicos e Análise dos Processos Erosivos. Anuário do Instituto de Geociências, v. 19, p. 93-114, 1996.

22. HENRIQUE, F. M.; FERNANDES, E. Caracterização do Meio Físico como Subsídio a Compreensão dos Processos Erosivos no Município De Pilões/PB. Revista GeoNorte, Edição Especial, v. 2, n. 4, p. 261-275, 2012. 
23. HERMUCHE, P.M.; GUIMARÃES, G.M.A.; CASTRO, S.S. Análise dos compartimentos morfopedológicos como subsídio ao planejamento do uso do solo em Jataí - GO. GEOUSP - Espaço e Tempo, São Paulo, n. 26, p. 113- 31, 2009.

24. INSTITUTO BRASILEIRO DE GEOGRAFIA E ESTATÍSTICA-IBGE. Cidades@. 2013. Disponível em: http://www.ibge.gov.br/cidadesat/xtras/perfil.php?codmun=510 $715 \&$ search=mato-grosso|reserva-do-cabacal. Acesso em 06 Set 2013.

25. INSTITUTO DE PESQUISAS TECNOLÓGICAS DO ESTADO DE SÃO PAULO - IPT. Orientação para combate à erosão no estado de São Paulo, Bacia do Pardo Grande. v. 3, (Relatório, 28: 184). 1990.

26. JUNQUEIRA， K.R.; CORRECHEL， V.; CUSTÓDIO FILHO, R.O.; SANTOS, F.C.V.; JUNQUEIRA, M.F.R. Estabilidade de agregados de um Neossolo Quartzarênico sob pastagem e mata em Baliza-GO. Enciclopédia Biosfera, v. 6, n.10, p. 1-7, 2010.

27. KAWAKUBO, F.S.; MORATO, R.G.; CAMPOS, K.C.; LUCHIARI, A.; ROSS, J.L.S. Caracterização empírica da fragilidade ambiental utilizando geoprocessamento. In: XII Simpósio Brasileiro de Sensoriamento Remoto. Goiânia-GO, 2005.

28. KEMPER, W.D.; ROSENAU, R.C. Aggregate stability and size distribution. In: KLUTE, A. Methods of soil analysis. Madison, Wisconsin, USA: American Society of Agronomy: Soil Science Society of America. 2ed, p. 425-443, 1986.

29. LEÃO, T.P.; SILVA, A.P.; MACEDO, M.C.M. Intervalo hídrico ótimo na avaliação de sistemas de pastejo contínuo e rotacionado. Rev. Bras. Ciência do Solo, v. 28, n. 3, p. 415-422, 2004.

30. LEPSCH, I. F.; BELLINAZZI Jr., R.; BERTOLINI, D.; Espíndola, C.R. Manual para levantamento utilitário do meio físico e classificação de terras no sistema de capacidade de uso. Campinas-SP. Sociedade Brasileira de Ciência do Solo, 1991. $175 \mathrm{p}$.

31. MARGOLIS, E.; SILVA, A. B.; REIS, O. V. Controle da erosão com diferentes práticas conservacionistas num solo litólico de Caruaru (PE). Revista Brasileira de Ciência do Solo, n. 9, p. 161-164, 1985. Disponível em: http://www.alice.cnptia.embrapa.br/bitstream/doc/477284/1/Ev apotranspiracaocultura.pdf

32. MATO GROSSO (Estado). Secretaria de Estado de Planejamento e Coordenação Geral. Moreira, M.L.C.; Vasconcelos, T.N.N. (Orgs). Mato Grosso: Solos e Paisagem. Cuiabá: SEPLAN, 2007, 272p.

33. MELO, M.R.S.; CAVALCANTE, J.S.J.; PORTELA, J.C.; SILVA, M.L.N.; REBOUÇAS, C.A.M. Atributos físicos de um Argissolo em ambiente de voçoroca no município de Mossoró, RN. Revista agropecuária científica no semi-árido, v. 10, n. 1, p. 01-06, 2014.

34. MERTEN, G. H.; MINELlA, J. P. G. Projeto de monitoramento ambiental de microbacias hidrográficas - RSRURAL, subprojeto 7. Porto Alegre, IPH-UFRGS, 2003.

35. MESSIAS, C.G.; FERREIRA, M.F.M.; RIBEIRO, M.B.P.; MENEZES, M.D. Análise empírica de fragilidade ambiental utilizando técnicas de geoprocessamento: $\mathrm{O}$ caso da área de influência da hidrelétrica do Funil -MG. Revista Geonorte, v. 2, n. 4, p. 112-125, 2012.

36. MINISTÉRIO DO MEIO AMBIENTE - MMA. 2007. Vulnerabilidade Ambiental, Desastres naturais ou fenômenos induzidos?.192p. Disponível

em: <http://www.inpe.br/crs/geodesastres/conteudo/livros/Vulnerab ilidade_ambiental_desastres_naturais_ou_fenomenos_induzido s_MMA_2007.pdf>. Acesso em 30 Jun2014.

37. MORGAN, R.P.C. Soil Erosion and Conservation. $3^{\text {a }}$ ed. BlackWell, 2005. 304p.

38. NUNES, M.C.M.; NEVES, S.M.A.S.; NEVES, R.J.; KREITLOW, J.P.; CHIMELLO, A.M. Susceptibility to Water
Erosion of Soils From the Municipality Salto do Céu, SW Mato Grosso State, Brazil - Brazil. Revista Geografia, v. 38, n. especial, p. 191-206, 2013.

39. OLIVEIRA, P.C.A.; RODRIGUES, G.S.S.C.; RODRIGUES, S.C. Fragilidade Ambiental e uso do solo da bacia hidrográfica do Córrego Pindaíba, Uberlândia, MG, Brasil. Revista Ambiente e Água, v. 3, n. 1, p. 112-125, 2008. 40. PROGRAMA DAS NAÇÕES UNIDAS PARA O DESENVOLVIMENTO - PNUD, Atlas do Desenvolvimento Humano no Brasil. 2013.Disponível em: <http://atlasbrasil.org.br/2013/perfil/reserva-do-cabacal_mt>. Acesso em 21 Set 2013.

41. RAMOS, F.T.; RAMOS, D.T.; CREMOM, C.; ROQUE, M.W. 2011. Erosão por salpicamento sob diferentes sistemas de manejo em um Neossolo Quartzarênico em Cáceres (MT). Global Science and Technology, v. 04, n. 01, p. 38-50.

42. RAMPIM, L.; TAVARES FILHO, J.; BEHLAU, F.; ROMANO, D. Determinação da capacidade de uso do solo visando o manejo sustentável para uma média propriedade em Londrina-PR. Bioscience Journal. Uberlândia-MG. v. 28, n. 2, p. 251-264, 2012

43. ROSS, J.L.S. Análise empírica da fragilidade dos ambientes naturais e antropizados. 1993. Disponível.em:<http://citrus.uspnet.usp.br/rdg/ojs/index.php/rd g/article/view/225/204>. Acesso em 31 Ago 2013.

44. SALA, M.G.; GASPARETTO, N.V.L. 2010. Fragilidade ambiental dos solos em bacias hidrográficas de pequena ordem: $\mathrm{O}$ caso da bacia do Ribeirão Maringá-PR. Boletim de Geografia, v. 28, n. 2, p. 113-126.

45. SALES, L.E.O.; CARNEIRO, M. A. C.; SEVERIANO, E. C.; OLIVEIRA, G.C.; FERREIRA, M. M. Qualidade física de Neossolo Quartzarênico submetido a diferentes sistemas de uso agrícola. Ciência Agrotecnologia, v. 34, n. 3, p. 667-674, 2010. 46. Salomão, F.X.T. Controle e Prevenção dos Processos Erosivos. In: Guerra, A.J.T.; Silva, A.S. S.; Botelho, R.G.M. (Orgs). Erosão e conservação dos solos: conceitos, temas e aplicações. Rio de Janeiro: Bertrand Brasil, p. 229-267, 2010. 47. SANTOS, G. G.; GRIEBELER, N. P.; OLIVEIRA, L. F. C. Chuvas intensas relacionadas à erosão hídrica. Revista Brasileira de Engenharia Agrícola e Ambiental. v. 14, n. 2, p. 115-123, 2010.

48. SILVA NETO, J.C.A.; NUNES, J.O.R. Potencial à erosão laminar utilizando Sistema de Informações Geográficas: aplicações na bacia hidrográfica do Rio Salobra-MS. In: XV Simpósio Brasileiro de Sensoriamento Remoto - SBSR, Curitiba, PR, 2011.

49. SILVA, F.A.S.; AZEVEDO, C.A.V. Versão do programa computacional Assistat para o sistema operacional Windows. Revista Brasileira de Produtos Agroindustriais, v. 4, n. 1, p. 7178, 2002.

50. SILVA, R.V.; REINERT, D.J.; REICHERT, J.M. Resistência Mecânica do solo à Penetração Influenciada pelo Tráfego de uma Colhedora em dois Sistemas de Manejo do Solo. Revista Ciência Rural, v. 30, n. 5, p. 795-801, 2000.

51. SOUZA, E.D.; CARNEIRO, M.A.C.; PAULINO, H.B. Atributos físicos de um Neossolo Quartzarênico e um Latossolo Vermelho sob diferentes sistemas de manejo. Revista Pesquisa Agropecuária Brasileira, v. 40, n. 11, p. 1135-1139, 2005.

52. SOUZA, L.H.C.; NUNES, M.C.M.; NEVES, S.M.A.S.; CHIMELlO, A.M.; CUIABANO, M. N.; GONZAGA, E.N. Densidade do solo sob diferentes níveis de degradação no sudoeste de Mato Grosso. In: II Reunião Oeste de Ciência do Solo, Rio Verde-GO, 2013.

53. TAGLIANI, C.R.A. Técnica para Avaliação da Vulnerabilidade Ambiental de Ambientes Costeiros utilizando um Sistema Geográfico de Informação. In: XI Simpósio Brasileiro de Sensoriamento Remoto INPE, Belo HorizonteMG, 2003.

54. TEODORO, V.L.I.; TEIXEIRA, D.; COSTA, D.J.L.; FULLER, B. B. O conceito de Bacia Hidrográfica e a 
importância da caracterização Morfométrica para o entendimento da dinâmica ambiental local. Revista Uniara, $\mathrm{n}$. 20, p. 137-156, 2007.

55. VALE JÚNIOR, J.F.; BARROS, L.S.; SOUSA, M.I.L.; UCHÔA, S.C.P. Erodibilidade e suscetibilidade à erosão dos solos de cerrado com plantio de Acaciamangium em Roraima. Revista Agro@mbiente, v. 3,n. 1, p. 1- 8, 2009.

56. VAN BAVEL, C.H.M. Mean weight diameter of soil aggregates as a statistical index of aggregation. Soil Sci. Soc. Am. Proc., Madison, 14:20-23, 1949.

57. VIEIRA, P.H.; BRAZ, A.M.; MIRANDOLA, P.H. A importância do Spring como uma ferramenta de análise ambiental: Caso da bacia hidrográfica do Uerê/MS. In: VIII Fórum Ambiental da Alta Paulista, v. 8, n. 2, p. 49-59, 2012.
58. VITTE, A.C.; MELLO, J.P. Considerações sobre a erodibilidade dos solos e a erosividade das chuvas e suas consequiências na morfogênese das vertentes: um balanço bibliográfico. Climatologia e Estudos da Paisagem, v. 2, n. 2, p. 107-133, 2007.

59. YODER, R. E. A direct method of aggregate analysis of soils and a study of the physical nature of erosion losses. Journal American Society Agronomy, Madison, Wisconsin, USA, v. 28, p. 337-351, 1936.

Manuscrito recebido em: 25 de Outubro de 2015 Revisado e Aceito em: 25 de Outubro de 2016 